\title{
Plant gene conservation
}

SIR-In recent months, controversy has arisen internationally over the conservation and availability of plant genetic resources, the genetic diversity of primitive varieties of crop plants and related wild species upon which future crop improvement programmes will depend.

Much of the controversy has centred upon the alleged exploitation by "gene-poor" countries of the "North" of the "gene-rich" countries of the "South", and upon the role of the International Board of Plant Genetic Resources (IBPGR) in genetic conservation programmes. The loss of genetic diversity contained in traditional varieties through their replacement by modern ones has occurred in most parts of the world. Many scientists worldwide have attempted to preserve this diversity by collecting and conserving it. They have been greatly supported by the efforts of IBPGR, which has catalysed activities and provided funds for their execution.

It is clear that, without adequate conservation strategies, many genetic resources would quickly be lost. One of the most effective ways is to store seed in gene banks, in which seeds are dried to a low moisture content and stored at low temperatures. Not all seeds can be stored in this way and, as with vegetatively propagated plant species, alternative methods such as tissue culture (in vitro culture) have been devised.

Three aspects of genetic resources work are now being called into question by various people, including the Canadian agricultural economist Pat Mooney. The first is that the countries of the north have "robbed" the southern countries of their genetic resources patrimony and are reluctant to return it to them. The second is that it is unwise to store genetic resources in seed banks because selection encourages the survival of genotypes best suited to survive under such conditions. The third is that IBPGR is supporting developed countries at the expense of the developing ones.

None of these allegations can be substantiated. Firstly, are the developed countries restricting the free flow of germplasm to the developing ones? We can find very little evidence of this. By and large, the record of northern countries in providing material for the southern ones is excellent. Thus the US Department of Agriculture (USDA) small grains seed bank at Beltsville, Maryland, has virtually never denied material to any country; not only basic germplasm but commercial varieties have always been made freely available. In 1983 alone, 150,000 samples of wheat and wheat relatives were distributed, and more than 50 per cent of these consignments were to overseas countries, mostly in the developing world. The same is true for countries in Europe that have gene banks: when available, seed is always sent to every bona fide scientist requesting it.

It is true that there have in the past been more seed banks in the developed countries than in the developing countries. This is because the whole concept of genetic conservation was formulated initially in the Soviet Union with Vavilov's work, and afterwards in the United Kingdom, Australia and the United States, with the Food and Agriculture Organisation of the United Nations (FAO) playing an important role.

The seed banks were also first established in the industrial countries because they possessed the technical knowhow and scientific resources.
Nevertheless, the industrial nations have financed the biggest operation the world has ever known to preserve genetic resources, and this they have done through special funding to IBPGR and the International Agricultural Research Centres (IARCs).

The second criticism questions whether genetic resources ought to be conserved in seed banks. There is now a considerable body of scientific data which clearly demonstrates that under good storage conditions seeds can be stored for $30-50$ years and possibly very much longer with little loss of viability or genetic erosion. In the absence of good storage conditions, the viability falls quickly and the germplasm is lost. Even under ideal storage conditions, the seeds must eventually be "regenerated" by growing out a new set of plants and obtaining fresh seed from them. If this is done carefully, selection can be kept to a minimum and the samples will not, as is alleged, become adapted to survive only in seed bank conditions.

Even allowing that a certain low level of selection may take place in seed banks, what is the alternative? Wild crop relatives may be conserved in nature reserves in some cases but, at present, there are not enough of these to deal with more than a minute fraction of the problem. Seeds of old crop varieties, it has been suggested, might be kept in special farm reserves in their places of origin. This is quite impracticable. There are some 130,000 accessions of wheat, 83,000 of rice, 14,000 of barley and at least 30,000 of maize in various gene banks, probably more. It would be quite impossible to grow these in their original areas, given the pressing need for land and food among developing countries. This land is needed for growing higher yielding, better adapted and more resistant varieties, which themselves are largely the result of the international use of freely available germplasm. There is thus an overwhelming case for the continuation of seed banks working to standards established by international committees set up by IBPGR. Such standards have been accepted by scientists all over the world. IBPGR has also recently established the basic procedures for in vitro gene banks, again working with distinguished scientists from northern and southern countries.

Finally we should like to counter the criticism aimed at IBPGR, that it is largely concerned with helping the developed countries. Nothing could be further from the truth.

IBPGR was established in 1974 as an autonomous international scientific organization under the auspices of the Consultative Group on International Agricultural Research (CGIAR). This latter body mobilizes financial support from donor countries and foundations to meet the budgetary requirements not only of IBPGR but also of the network of IARCs such as the International Rice Research Institute (IRRI) in the Philippines, and others dealing with a wide range of crops. All these centres have germplasm programmes, storing genetic resources of their respective crops mainly as seeds but also, where appropriate, in vitro conservation is being developed. Their germplasm work has received considerable financial support from IBPGR, and they have used this germplasm to provide improved breeding material for national breeding programmes in developing countries.
IBPGR also supports national genetic resources efforts, has financed and encouraged work in the developing world, and has trained numerous developing country scientists. It has financed 300 collecting missions in approximately 90 countries and provided basic equipment for the national gene banks in 28 developing countries. In respect of storage facilities, IBPGR has reached agreement with 31 countries for long-term storage, of which 25 are located in developing countries. As 80 per cent of all these long-term germplasm storage centres are in developing countries, those who assert that IBPGR intends that the developed countries should continue to hold most of the world's germplasm are clearly mistaken. What developed countries have accomplished is to collect and hold in trust the genetic resources of the developing countries. They have now returned a considerable part of these and are only too happy to return any or all of the rest that the developing countries may desire.

IBPGR, in common with the CGIAR system of IARCs, is promoting active use of this germplasm, through schemes for its evaluation and development into better adapted, higher yielding, more nutritious and more disease-resistant varieties for developing countries.

We conclude that genetic resources conservation is in competent hands and should remain there. What is becoming abundantly clear is that the germplasm policies of IBPGR, the IARCs and CGIAR are producing results through wise allocation of funding and genetic resources materials. Where the infrastructure is present, these policies pay off handsomely, thus providing the potential for improved wellbeing and economic advancement in the developing countries.

M.H. ARNOLD (Plant Breeding Institute, Cambridge), D. Astley (National Vegetable Research Station, Warwick), E.A. BELL (Royal Botanic Gardens, Kew), J.K.A. Bleasdale (National Vegetable Research Station, Warwick), A.H. BuntrNG (University of Reading), J. BURLEY (University of Oxford), J.A. CALlow (University of Birmingham), J.P. COOPER (Stroud, Gloucestershire), P.R. DAY (Plant Breeding Institute, Cambridge), R.H. Ellis (University of Reading), B.V. FORD-LLOYD (University of Birmingham), R.J. Giles (Plant Breeding Institute, Cambridge), J.G. HAwKES (University of Birmingham), J.D. HAYES (University College of Wales, Aberystwyth), G.G. Henshaw (University of Bath), J. Heslop-Harrison (Welsh Plant Breeding Station, Aberystwyth), V.H. HEYwood (University of Reading), N.L. INNES (Scottish Crop Research Institute, Dundee), M.T. JACKSON (University of Birmingham), G. Jenkins (Plant Breeding Institute, Cambridge), M.J. LAwrEncE (University of Birmingham), R.N. LESTER (University of Birmingham), P. Matrhews (John Innes Institute, Norwich), P.M. MUMFORD (University of Birmingham), E.H. ROBERTS (University of Reading), N.W. Simmonds (University of Edinburgh), J. SMARTT (University of Southampton), R.D. SMITH (Royal Botanic Gardens, Kew), B. TYLER (Welsh Plant Breeding Station, Aberystwth), R. WAtKins (East Malling Research Station, Maidstone), T.C. WHITMORE (University of Oxford), L.A. WITHERS (University of Nottingham) 